\title{
War Crimes Tribunals in Bangladesh: A Socio-Political and Legal Impact Analysis ICSR
}

\author{
Md. Abdul Jalil \\ Associate Professor of Law, Department of Business Administration, Faculty of Economics \\ and Management, International Islamic University Malaysia \\ Email: Abd_Jali12@Yahoo.Com, Abduljalil@ Iium.Edu.My
}

Accepted: August 28, 2012 Published: September 29, 2012

Doi:10.5296/jsr.v3i2.2484

URL: http://dx.doi.org/10.5296/jsr.v3i2.2484

\begin{abstract}
Till 1970, Bangladesh was still an underdog state of West Pakistan and the people of the future "Bangladesh" were gravely displeased with the Government of Pakistan that governed "Bangladesh" for various reasons of bad governance and hypocritical administration. As a result, "Bangladeshi" people declared an independence movement in March 1971 to relieve themselves from the yoke of gross incompetent governance of the ruling Government. The Freedom Fighters of Bangladesh fought a liberation fight against the Pakistani Army for 9 months after which they were ultimately and decisively victorious on 16 December 1971 and emerged as an independent country named as 'Bangladesh'. After the independence of Bangladesh, Sheikh Mujibur Rahman, the first Prime Minister of Bangladesh, enacted the International War Crimes (Tribunals) Act 1973 (IWCTA 1973) to punish the war criminals during the 9 months of liberation movement. The object of this paper is to critically analyze the provisions in the IWCTA 1973 in light of the international war crime laws find its deadly flaws.
\end{abstract}

Keywords: International crimes, war crimes, crimes against humanity, International Crimes Tribunals Act 1973, investigation, prosecution, trial, punishment.

\section{Introduction}

After a long struggle of independence against the English rule in the Indian subcontinent, the English people agreed to leave India in 1947. In that year Pakistan was formed as a federal state consisting of East Pakistan (now known as Bangladesh) and West Pakistan (now known as Pakistan) as being separated from the Indian subcontinent. The objective of establishing a new state by the name 'Pakistan' was to rule this new country by the Muslims who had not the slightest wish to remain with India and to be ruled by the Hindu politicians of India due to a long period of bitter experiences suffered by the Muslims in the Indian sub-continent during the English rule. Another objective of forming Pakistan was to establish an Islamic State which will be developed with all aspects of good, fair and genuinely responsible governance 
managed by people of the highly intellectual class of the society. Unfortunately, the objectives were not fulfilled due to the pure lack of academic intelligence, which normally resulted in negligence and arrogance of the Pakistani rulers who were from the West Pakistan.

The rulers of West Pakistan had harbored an ungovernable, overtly and undying political grudge against the East Pakistan state as well as against the highly intellectual and honest citizens who have along been discriminated on different political aspects, such as, determining the national language of Pakistan, the socio-political development, including the economic and industrial development, etc. It is prominently and historically worth mentioning here that in 1970, about 250,000 people died in Bangladesh due to an unprecedented devastation by a cyclone from the Bay of Bengal, and even though the cyclone created a massive holocaust known throughout the whole world, nevertheless the military Government of Pakistan at that time, led by General Yahia was totally indifferent to the cyclone victims in Bangladesh and did not lift a finger of authority to provide enough relief materials for the millions of hungry and diseased ridden people to alleviate their sufferings in East Pakistan, in spite of the irrevocable fact that the majority of the West Pakistan people had close relatives in East Pakistan. To highlight his historic, unbridled sadistic character which only a few world leaders could match, he purposely failed the mission to solicit foreign assistance for the deadly disastrous devastation in coastal Bangladesh caused by the cyclone (Unigroup, online). During the nine months of war, six political parties in Bangladesh opposed the separation of Bangladesh from Pakistan and assisted the Pakistani Army to arrest and kill the members of the Bangladesh Freedom Fighters. The Pakistani Army and the supporters of the Army (six political parties) were involved in the heinous and barbaric crimes against fellow humans of similar religion and similar ancestry in Bangladesh.

In 1973, the first Prime Minister of Bangladesh, Sheikh Mujibur Rahman enacted the International War Crimes (Tribunals) Act 1973. Under this Act thousands of people were investigated including the Pakistani Army officers. After the investigation, the war crime charges were proved against 195 Pakistani Army officers, and no Bangladeshi citizen was identified as war criminals. However, these 195 Pakistani war criminals were accorded an amnesty and were safely returned to Pakistan after the establishment of a tripartite agreement between the Bangladesh-India-Pakistan in 1974 under the instruction of the Prime Minister of India, Mrs. Indira Ghandhi (CPD Jamat, 2008: 24-30). Subsequently different parties came to the political power in Bangladesh, such as, President Ziaur Rahman of Bangladesh Nationalist Party (BNP), President H.M. Ershad of Jatio Party (JP), Prime Minister Khaleda Zia (from BNP), Prime Minister Sheikh Hasina (from Awami League (AL), but none of them took any initiative to investigate and to reveal the Bangladeshi war criminals during the last 40 years.

As said earlier, there were six parties who opposed the separation of Bangladesh from Pakistan. Bangladesh Jamaat-e-Islami (known as Jamaat) was one of the six parties which opposed the separation of Bangladesh from Pakistan for reasons considered good to them in 
the prevailing circumstances at that time as said by top Jamaat leaders on many occasions and that was published in different daily newspapers in Bangladesh. For the last 40 years the top leaders of Jamaat have been saying that they only opposed the separation of Bangladesh peacefully by organizing rally and by giving speech to the people in support of an undivided Pakistan. They were not involved in any war crimes or international crimes, such as, murder, rape, arson, looting, etc. (A.S.M. Rob, 2010). The Pakistani Government formed "Rajakar", a para-militia to assist the Pakistani Army Government to find out members of the Freedom Fighters in Bangladesh. 'Rajakar' is an urdu word which means "assistant or helper or collaborator". The Bangladesh Collaborators (Special Tribunal) Order 1972 (herein after referred to as 'the Collaborators Order 1972') was enacted in 1972 by the then AL government. About 100,000 people were arrested and investigated in order to weed out the Rajakars. Out of these 100,000 people, only 752 people were found guilty for collaboration and they were given jail sentences for different periods (Abu Rawsab, 2010; Jalil, M.A., 2010: 110-120). No Jamaat leader or member was among the 752 guilty people who were Rajakars (Jalil, M.A., 2010: 110-120). This means that no Jamaat leader or member was identified as a Rajakar or a war criminal during the rule of Sheikh Mujibur Rahman from 1972-1975. It is also well-known to the people of Bangladesh that during the Mujib regime from 1972-1975 there was no war crime or criminal cases were filed against any Jamaat leaders by any 1971 war victims.

Actually for the past 38 years (1972-2009) no person had ever filed any war crimes or international crimes suit against any Jamaat leaders or members in any police station in Bangladesh. This proves beyond a shadow of doubt that no Jamaat leader or member had ever been involved or had ever taken part in the war crimes or international crimes in 1971 during the nine-month liberation struggle (BJI, 2009: 9). However, only in 2010 some hardcore AL workers filed false war crimes cases against the top Jamaat leaders with political motive as instructed from the top level of the ruling party. In 2010 the Awami League (AL) Government had amended the International War Crimes (Tribunal) Act 1973 (the IWCRA 1973) and renamed it as the International Crimes (Tribunals) Act 1973 (ICTA 1973) and being armed with this amended Act, the Awami League Government forthwith arrested the top 5 Jamaat leaders to stand on trial for the alleged international crimes committed in 1971, after a time lapse of 38 years. The strangest and most bewildering political phenomenon was that not a single person from the other five political parties had been arrested for the international war crimes although there were collaborators and war criminals in those five parties who made up the 752 found guilty out of the 100,000 people. Even though it is a public knowledge that there are international criminals and Rajakars in the Awami League (AL) party itself (the ruling party) but none of them have ever been arrested for trial mainly because they are supporters of the present AL Government. The Jamaat political party leaders are the only ones arrested out of malice and with mala fide political motive as the people of Bangladesh are well aware of whereas this typical political scenario is well known and well acknowledged by the educated and conscientious people nationally and internationally as a real political vendetta against the Jamaat leaders to weaken the political strength of this popular democratic party and to illegally force it not to make coalition with the largest 
political party in Bangladesh known as BNP (Jalil, 2010). Only political idiots with prejudiced minds, jaundiced eyes and mental aberration will agree with this type of governance for the country.

As earlier has been mentioned in this paper, the objective of this paper is to critically review the recently amended International Crimes (Tribunals) Act 1973 (amended in 2010) to establish beyond a shadow of doubt on its inconsistency with the Constitution of Bangladesh and the international conventions related to war crimes and other laws in Bangladesh. Descriptive and analytical research methodology has been applied in this paper to critically evaluate some serious legal discrepancies found in the sensitive provisions in this impugned Act.

\section{Critical Evaluation Of Icta 1973}

In this sub-topic we will critically evaluate some of the sensitive provisions of the ICTA 1973 which violate the human rights and the democratic rights of an accused person under the Act and they are contradictory with the Constitution of Bangladesh and other laws in Bangladesh; and international conventions, such as, i.) Universal Declaration of Human Rights (UN); ii.) International Covenant on the Civil and Political Rights (UN) (Central Publicity Dept of Jamaat, 2008: 14).

According to Khan, The International War Crimes (Tribunal) Act, 1973 (IWCTA 1973) was enacted by the Parliament of Bangladesh in 1973 to try and adjudicate the offences of genocide, crimes against humanity, war crimes and other crimes under the International law as disclosed in the preamble. To understand any statute in its proper sense a close study as well as a scrutiny of the preamble and diverse sections of the statute is very much needed. A conscious study of the whole Act reveals that it was enacted to try the members of the Armed Forces to whom the Army Act 1952, the Air Force Act, 1953 and the Navy Ordinance, 1961 can be applied and the Auxiliary Forces who committed the offences mentioned in section 3(2) of the International Crimes (Tribunal) Act, 1973 (Bangladesh) (ICTA 1973 as amended in 2010). Due to the presence of different provisions in the Act which take away the fundamental procedural rights and the international standard rules of evidence which is applicable in the crimes against humanity, it is absolutely impossible to be liberated from punishment on ordinary civilians especially who possess the citizenship of Bangladesh (Khan, 2010). Thus, the IWCTA 1973 or the ICTA 1973 cannot be applicable on any Bangladeshi citizen who has been accused of the international crimes or the war crimes as both Acts are ultra vires of the Constitution of Bangladesh and other procedural and evidential laws applicable in Bangladesh. These Acts are also contradictory with the international conventions on war crimes including the Geneva Conventions on war crimes and the Rome statute of International Criminal Court (ICC).

According to Gary D. Solish on section 3(d) of ICTA 1973 Bangladesh, war crimes are serious violations of the laws applicable in an armed conflict (also known as the international 
humanitarian law) which gives rise to an individual criminal responsibility. Examples of such conduct includes "murder, extermination, rape, ill-treatment or deportation of civilian residents of an occupied territory to slave labour camps", "the murder or ill-treatment of prisoners of war", "the killing of hostages", "the wanton destruction of cities, towns and villages, and any devastation not justified by military, or civilian necessity" (Solish, 2010).

\section{Jurisdiction of the Tribunal}

Section 3 of the ICTA 1973 states the jurisdiction of the tribunal, which may be established under section 6(1) of the Act by the Government through a notification in the official Gazette. Such Tribunal has already been firmly and irrevocably established by the Awami League Government in the middle of 2010 of which Sub-section (1) of Section 3 of the above Act provides, "A tribunal shall have the power to try and punish any person irrespective of his nationality who, being a member of any armed, defense or auxiliary forces commits or has committed, in the territory of Bangladesh, whether before or after the commencement of this Act...." A plain reading of this sub-section reveals that the tribunal shall have the authority to exercise jurisdiction over any person belonging to the armed, defense or auxiliary forces only. The nationality of the accused has been disregarded. A person who never belonged to the said forces cannot be tried and punished by any tribunal established under the ICTA 1973. The definition of auxiliary forces given in the Act is vague also. Section 2(a) of the Act provides " 'auxiliary forces' includes forces placed under the control of the Armed Forces for operational, administrative, static or other purposes."

The top Jamaat leaders of Bangladesh who have been arrested with political malice and vendetta in July 2010 to be tried under the Act for international crimes did not belong to any armed or auxiliary forces as defined under section 2(a) of the Act. The arrested Jamaat leaders have been denying this allegation for the last 40 years that they had never been involved in any armed or auxiliary forces and there was no criminal case that had ever been filed against them in any police station in Bangladesh for war crimes or international crimes for the last 40 years. Their statements were published in different newspapers in Bangladesh, such as, the Daily Sangram, The Daily Star, The Daily New Nation, The Daily Nayadiganta, The Daily Amar Desh, the weekly Sonar Bangla, just to name a few, and the people of Bangladesh have all along been aware of this dastardly anomaly. It seems that some phenomenal judicial blindness has taken place right to the very core of the high judicature of Bangladeshi courts of law, the existence of which has always been manifestly proven by the fact that as the ICTA 1973 does not have fair procedural and evidential rule and excludes certain fundamental laws of Bangladesh from application in the Tribunal, not a single Bangladeshi citizen can be tried under the Act unless the above mentioned serious faults are amended in the Act first as mentioned by the US Senator and Member of the Congress Mr. Boozman in his pertinent letter to the Prime Minister of Bangladesh, Sheikh Hasina (Please see Appendix 2). One begins to wonder whether the legal officials in the Bangladeshi judicature or the judiciary department have ever undergone any formal legal courses during their law schooling periods because they 
seem to be very highly inclined towards the miscarriage of justice while reframing the amendments.

The rule of law, the internationally recognized rule of evidence, the international standard of burden of proof by the prosecution, the proper procedure in the criminal court, etc., form part of the basic structure of the Constitution and it cannot be changed by enacting any law as said by the Appellate Division of the Supreme Court of Bangladesh in the historic Eight Amendment case which has been reported in 1989 BLD (SPL) 1. In the Kesavananda case, the Chief Justice of the Supreme Court of India, Chandrachud, said that the fundamental rights, being an essential part of the Constitution of India could not be abrogated or emasculated by the Parliament (AIR 1973 SC 1461). Hence judicially, the ICTA 1973 has been an illegal and black law as they brazenly, unmercifully and lawlessly rob the fundamental rights of the citizens of Bangladesh just to quench their political revenge on their political rivals.

Section 6(8) of the 1973 Act states that the accused or his counsels cannot challenge the constitution of the international crimes Tribunal set up in Bangladesh under the 1973 Act and the appointment of its Chairman or members.

This section gives a license to the AL Government to administer the abuse of power. At present the AL Government is abusing its power by illegally arresting renowned opposition political leaders on false and prefabricated cases; beating and mentally oppressing them seriously during periods of brainwashing and relentless indoctrination and disrupting the victims' sleeping periods with intermittent loud blaring music as well as throwing bucketful of icy cold water on them while sound asleep. Recently, Salahuddin Qader Chowdhury, the present popular MP of Bangladesh Parliament and a strong standing committee member of the Bangladesh Nationalist Party (BNP) was arrested on the night of 16 December and on that night he was seriously beaten by the police who faithfully executed the order of the AL Government to the letter. The AL Government and the police have, as is usually the case, later denied the beating although the doctor who had earlier treated him in the morning had found that his whole body was bloody black and blue while his shirt was torn and tattered, as if had been run through a potato skin peeling mill, as a result of some form of unmerciful severe assault from a band of political hooligans of the lowest order.

As a matter of well substantiated fact, the people of Bangladesh are afraid of the Awami League party as it has conducted its political affairs in the form of an oppressive political party in Bangladesh since the independence of Bangladesh in 1973 and earlier in order to gain the public consent. Under section 6(8) of the 1973 Act as mentioned above, the aggrieved party cannot obtain a remedy even if the Tribunal is legally constituted as there exists a rampant bias in the constitution of the Tribunal and the questionable appointment of its judges and prosecutors with questionable legal background, if any. Hence, section 6(8) of the 1973 Act is unrepentantly violating the fundamental rights and the fair trial procedure in the criminal court which aims to ensure that no innocent person is wrongly or politically persecuted by the court or the Government unless justifiably proven guilty in the unbiased court of law. 


\section{Appointment Of Prosecutors}

Section 7(1) of the 1973 Act provides that "The Government may appoint one or more persons to conduct the prosecution before a Tribunal on such terms and conditions as may be determined by the Government and every such person shall be deemed to be a Prosecutor for the purposes of this Act. Subsection 7(2) provides that the Government may designate one of such person as the Chief Prosecutor."

The important point here is that the Prosecutors appointed by the Government must be impartial persons. They must not be members or supporters of the ruling political party. This is to insure that the Prosecutors act fairly and impartially against the accused.

Unfortunately the fact that the prosecutors and investigation agency established under the 1973 Act are hardcore supporters of the Awami League Government (otherwise these so called prosecutors would, in the first place, never have passed their job interviews with flying colours) and the AL Government has planned to find the accused guilty by any fair or foul means, especially, with implication of concocted notorious political motives to destroy a prominent democratic political party in Bangladesh. Such plan of the AL Government has been published in different newspapers in Bangladesh in different times, especially, in 2009 and 2010, but no sane citizen would dare to lift a finger to comment, much less to protest. A few Ministers of the present Government gave open statement in the press that Jamaat leaders will be arrested and hanged for war crimes prior to their arrest and trial in the Tribunal. Such Ministers are the Law Minister (who may not even understand the term 'ultra vires'), Law Deputy Minister, Minister of State Affairs, etc. Therefore, free, fair and impartial investigation and trial of the accused are not possible and would not even have the shadow of a hope neither the ghost of a chance to be free under the Awami League regime.

\section{Investigation Agency's Power}

The Bangladesh Government may establish an Investigation Agency to assist prosecutors appointed under the 1973 Act in which Section 8 of the Act provides that the Government may establish an agency for the purposes of investigation into the crimes and any officer belonging to the Agency shall have the right to assist the prosecution during the trial. Any person appointed as a Prosecutor is competent to act as an Investigation Officer and the provisions relating to investigation shall apply to such Prosecutor (section 8(2) of ICTA 1973).

Section 8(2) of the 1973 Act allows a prosecutor to act as an investigation officer and is not fair in any civilized judicial inquiry as the same person cannot be a prosecutor and an investigation officer at the same time. It is a total violation of one of the fundamental principles of natural justice which is known as the 'rule against bias' in which it is prominently stated that the investigation officer will investigate the offences levied against 
the accused and will accordingly provide an unbiased written report on the investigation to the prosecutor. The function of the prosecutor is to prosecute the accused based on the investigation report. He can prosecute an offender only when there is adequate evidence against him. A prosecutor cannot perform two functions at the same time as a prosecutor and as an investigation officer, while it is universally acknowledged by the competent legal circles that an investigation officer can never simultaneously act as a prosecuting officer, unless he is endlessly hallucinating while performing his duty. A conflict of interest is thus created and the element of bias is always the basis of conclusion arrived at. This has always been the true case of an act of perpetration of bias, especially, when the criminal case is glaringly politically motivated as far as the present trial of the top Jamaat leaders in Bangladesh are concerned, and as fully convinced by the impartial different international human rights organizations, international personalities and the international legal fraternity, to name a few.

In fact it is beyond a shadow of doubt that the Awami League (AL) Government has appointed prosecutors and investigation officers who are hardcore supporters of the AL Government as it is well known to the people of Bangladesh about this lopsided anomaly and comments on this bias and political appointment were duly reported in different daily newspapers all over Bangladesh. ${ }^{1}$ Hence, it is crystal clear that the prosecutors and investigation officers appointed by the AL Government are not impartial and obliquely one-sided primarily because an impartial and a fair investigation report is not the order of the day of the ruling party. This legal discrepancy has been further luridly enhanced by reports in the newspapers that the investigation officers are offering bribes to AL supporters to collect mindless witnesses as they even resort to acts of threat to some people that those who do not want to be witnesses against the accused, the prosecutors will in turn sue them on concocted false cases in the court as means of harassment. ${ }^{2}$ One begins to wonder whether these highly trained or untrained officers can be the most suitable candidates for the posts of compatible cellmates of a lunatic asylum.

Section 8 of the International Crimes (Tribunal) Act, 1973 deals with investigation by investigation officers and by virtue of this section the investigation officers are authorized to examine any person who appears to be acquainted with the facts and circumstances of the case. Under Section 8(5) of the Act such person shall be bound to answer all questions put to him by an Investigation Officer and shall not be excused from answering any question on the ground that the answer to such question will incriminate or may tend directly or indirectly to incriminate him. Although no such answer which a person shall be compelled to give, shall subject him to any arrest or prosecution, or be proven against him in any criminal proceeding, but it should not be ignored that section 8(5) of the 1973 Act is ultra vires of the provision of article 35(4) of the Constitution of Bangladesh and the Code of Criminal Procedure of Bangladesh. A person including an accused has the legal right to be silent on questions asked to them if the answer may incriminate him. This is a fundamental criminal right given to the

\footnotetext{
1 The Daily Sangram, 2010; The Daily Naya Diganta, 2010; The Daily Amar Desh, The Daily New Nation etc. published from Bangladesh.

2 The Daily Star 2010; The Daily Sangram, 2010 etc. published from Bangladesh.
} 
accused or a witness, but section 8 of the 1973 Act has blatantly denied the accused this fundamental right.

In view of the foregoing untenable situational circumstances arising therefrom, many people are afraid of the present Government which can be appropriately and concisely described as an oppressive and terrorist Government as amply stated earlier which manifestly reflect their inherent fear and respect of the Jamaat Party with its charismatic objective which will one day be the truly peaceful and responsible Government that the AL Party has all along been hallucinating to achieve. This is further reinforced by the fact that the supporters of the present Government together with the police force have already killed countless opposition leaders in broad day light in public on the street by beating them with sticks and rods and have wantonly bodily injured thousands of the opposition party members during peaceful gathering and human chain demonstrations. The Police and the AL Government supporters are working together, hand-in-hand, no, hand-in-glove, to beat those who criticize and oppose this Government's negative acts which go against the national interest and the inherent sanctity of independence of the country. The people of Bangladesh are endlessly counting their number of days when Allah (God) will remove this domineeringly insane and sadistic Government from the political power of the nation.

\section{Fair trial in the Tribunal}

Section 10 of the 1973 Act requires the Tribunal to adhere to specific procedures. This section provides certain procedures which the Tribunal must follow (Section 10 of ICTA 1973). Section 10 of the Act provides fair procedures for the trial of the accused, but the fact that the three judges already appointed for the Tribunal are not impartial, defeats the very provision as their political philosophy of fair is foul and foul is fair is being generously implemented. They are hardcore supporters of the present Awami League (AL) Government and in such a very one-sided case, a legally fair and impartial judgment is not possible against the accused persons although section 10 provides fair procedures for trial of the accused. It is rightly inferred here that as mostly mentioned above that the AL Party leaders have previously seen the performance of the charismatic Jamaat Party leaders and found their rival political philosophy was so magnanimous that the AL Party leaders began to realize that their AL Party would soon be eclipsed and be swept away into oblivion. There is no other rational way to explain the AL Party's erratic mode of administering the Government in such an uncivilized manner.

Besides, section 6 is contradictory with section 10 of the ICTA 1973 whereby Section 6 of the ICTA governs the establishment and general structure of the Tribunal. The particular concern to the War Crimes Committee (WCC) of International Bar Association (IBA) of the UK, are certain provisions within this section that compromise the fairness and impartiality of the Tribunal, as they are inconsistent with good international practice. The WCC of IBA gave many adverse opinions against the ICTA 1973 when this agency was requested by the UK Parliament Human Rights Group to conduct a legislative review of the International Crimes 


\section{MInstitute Macrothink $^{m}$}

Tribunals Act 1973 (Bangladesh) and provided an opinion it was not consistent with the current international criminal law standards. ${ }^{3}$ Similarly, Her Excellency the US Secretary of State Hillary Clinton has also expression her concern to the Prime Minister of Bangladesh Sheikh Hasina by Tele-Talk on 15 January where she urged that the Government of Bangladesh must make sure that the war crimes Tribunal is fair and impartial and it is not politically motivated. Her Excellency also observed that the Tribunal must follow international standard war crimes law. Therefore, it is necessary to further amend the ICTA 1973 to fully conform it to the international standard (Hillary Clinton, 2011). Subsection 6(5) of the 1973 Act states:

"If, in the course of a trial, any one of the members of a Tribunal is, for any reason, unable to attend any sitting thereof, the trial may continue before the other members."

This section is contrary to the international practice, which would provide that if any one of the members of the Tribunal was unable to attend a hearing, the trial would be adjourned. The concern is that if a trial continued without all Tribunal members present, it could affect the authority and trustworthiness of the process resulting in a miscarriage of justice. On 13 January 2011, in a Press Conference in Dhaka, Bangladesh Honorable US Special Ambassador for War Crimes, Stephen Rapp said that: 'The ICTA 1973 is not of international standard'. (Stephen Rapp, 2011).

Subsection 6(8) of the 1973 Act is also problematic because of its potential to compromise the fairness of the Tribunal. It states:

"Neither the constitution of a Tribunal nor the appointment of its Chairman or members shall be challenged by the prosecution or by the accused persons or their counsel."

\footnotetext{
3 War Crimes Committee (WCC) of IBA, UK, Inconsistency of Bangladesh's International Crimes (Tribunals) Act 1973 with International Standards. Dhaka, Bangladesh: Society Watch, 2010, at 5-6. The WCC of IBA after reviewing the 2010 amendment observed that:
}

i) The 1973 legislation, together with 2010 amending text, provides a system which is broadly compatible with current international standards. However, there are some areas which now appear out of date, having fallen behind the more recent practice in international tribunals. This includes the basic definition for some of the crimes, as well as the penalty available upon conviction.

ii) The area of greatest concern is with respect to the rights protecting the interests of individual on trial. Here there are some significant omissions of the accepted international standards. The most basic account of those standards is set out in Article 14 of the International Covenant on Civil and Political Rights. Although a number of those standards are included within the 1973 legislation, there are others which are not, and would therefore leave a Bangladesh tribunal open to criticism.

iii) Moreover, the rights of an individual during the investigation stage (as opposed to during trial) are separately identified in the text which established the International Criminal Court. These are missing from the Bangladeshi legislation. 
The special US Ambassador for War Crimes to Bangladesh in a press conference on 13 January 2011 in the American Club at Dhaka, Bangladesh, said that the International Crimes Tribunals Act 1973 (Bangladesh) (ICTA 1973) must be amended to make it in conformity with the International Criminal Court (ICC) of law and legal procedure. The trial of the accused for war crimes must be impartial and of international standard to be credible. His Excellency had said that the 1973 Act was not of an international standard. He emphasized that the trial of the accused for war crimes must be fair and impartial and it should not be politically motivated. He met the Prime Minister of Bangladesh, Sheikh Hasina to discuss about war crimes trial issues and observed the Government must make sure that no innocent person is wrongly punished for war crimes (Stephen Rapp,2011).

Similarly, the honourable US Senator Mr. Boozman had expressed a great concern to the Prime Minister of Bangladesh, Sheikh Hasina on December 2010 in a personal letter to her (please see Appendix 2) that the ICTA 1973 does not meet the international standards of war crimes law provided in the Geneva Conventions and Rome Statute of ICC laws. In his letter to the Prime Minister, the honourable US Senator Boozman has observed that:

"I am concerned that unless the law is updated to be consistent with international law, it will be impossible to adequately protect human rights of the accused. In addition, the law as it currently stands undermines your country's efforts to eliminate impunity and create the impression among the international community that the process could be used as a tool for political revenge or retribution. It has been noted through media reports that several prominent members of Jamaat-e-Islami have been arrested and detained on the lesser charge of offending religious sentiment. Once these persons were in police custody they were then questioned about war crimes. Again, the Tribunal's procedures call into question the political impact of the Act. Since Jamaat is closely aligned to your Government's main opposition party, the perception exists that one of the Tribunal's primary roles is to reduce support for the opposition. By updating the Act and guaranteeing fairness and neutrality of the process for the accused, your Government will demonstrate its commitment to guard against impunity and promote justice."

As usual, this historically sarcastic letter from the honorable US Senator Boozman did not deliver any impact on the ruling party as most of the party members have begun to grow thick skin since being in power. To begin with, it is highly essential to ensure fairness of the Tribunal in that the accused must have the right to challenge either the constitution of the Tribunal or the appointment of certain of its members, otherwise prejudice secretly creeps up during trial. As a result, the WCC of IBA recommended that (i) subsection 6(5) of the 1973 Act should be amended so that if any one of the Tribunal members is unable to attend a hearing, the trial is adjourned. (ii) A provision should be added allowing for challenges to the constitution of the Tribunal or appointment of its Chairman or members based on impartiality. A different chamber (preferably a Chamber of appeal) ${ }^{4}$ should adjudicate challenges to

\footnotetext{
${ }^{4}$ The Special Court for Sierra Leone (SCSL) for war crimes trial had two chambers. Those two Chambers were Trial
} 
Tribunal members within a limited and fixed time frame to ensure a speedy recommencement of the trial itself (WCC of IBA, 2010: 16).

\section{The High Court Division has been made dependent upon the Tribunal}

Section 13 of the ICTA 1973 states that "No trial before a Tribunal shall be adjourned for any purpose unless the Tribunal is of the opinion that the adjournment is in the interest of justice."

In fact, section 13 makes the High Court Division (HCD) dependent upon the tribunal. It is up to the discretion of the HCD to decide whether a proceeding should be adjourned or not after applying its sense and conscience to facts as well as circumstances of each case in hand. That is why section 13 is curtailing the discretionary power of the High Court Division that is not tenable in law. This section also infringes upon the rule of 'natural justice' by empowering the Tribunal (formed under ICTA 1973) to decide in de facto manner in its own cause. Therefore, section 13 is violating the principle of natural justice, i.e., 'no one shall be judged in its own cause' and that is why, this section should be declared null and void (Hhan, 2010).

\section{Rules Of Evidence}

It is a well-established jurisprudential principle that in criminal cases, the prosecution has to prove the case 'beyond a reasonable doubt' with adequate primary and secondary evidence. If the case is not proven beyond a reasonable doubt, the Tribunal must acquit the accused. The problem is that some of the provisions of the 1973 Act contradict with the solemn Constitution of Bangladesh and other laws and with the doctrine of 'Basic Structure of Constitution', which has already been established in India and recognized in Bangladesh by the Appellate Division of the Supreme Court of Bangladesh in the historic Eight Amendment case reported in 1989 BLD (SPL) 1. The doctrine was primarily established in India by the decision of the Indian Supreme Court in the Kesavananda and Indira Gandhi case popularly known as the Election case reported in AIR 1973 SC 1461 and AIR 1975 SC 2299 respectively (Khan, 2010). In these two cases the court held that the fundamental rights provided in the Constitution cannot be taken away in any manner. All citizens have the right to claim those fundamental rights even though they are tried for criminal offences.

Section 19(1) of the 1973 Act provides that "A Tribunal shall not be bound by technical rules of evidence; and it shall adopt and apply to the greatest possible extent expeditious and non-technical procedure, and may admit any evidence, including reports and photographs published in newspapers, periodicals and magazines, films and tape-recordings and other

Chamber and Appeals Chamber. The Trial Chamber consisted of 2 international and 1 local judges and the Appeals Chamber consisted of 3 international and 2 local judges. Bangladesh Government may adopt similar two Chambers of the war crimes Tribunal to ensure fairness and impartiality of the judgments of the Tribunal. His Excellency the US Senator Mr. Boozman has impliedly recommended such two Chambers of the war crimes Tribunal in Bangladesh in his pertinent letter to the Prime Minister of Bangladesh, Sheikh Hasina. Similarly, such two Chambers trial court for war crimes was also followed in Extraordinary Chambers in the Courts of Cambodia (ECCC) for the trial of genocide in Cambodia. This Extraordinary Chambers in Cambodia was established by UN-Cambodia Agreement (See Appendix 1). 
materials as may be tendered before it, which it deems to have probative value." (Section 19(1) of ICTA 1973).

The above section is defective and contradictory with the Evidence Act of Bangladesh and international war crimes conventions. It provides that the Tribunal formed under the 1973 Act shall not be bound by technical rules of evidence and it can adopt a non-technical procedure. Such provision is clearly bias and against the concept of fair trial and justice. In such a case, it is evidently clear that the above section should be deleted from the Act. It makes the 1973 Act ultra vires of other relevant laws in Bangladesh including the Constitution of Bangladesh and the international conventions.

An international crimes Tribunal cannot pass a death sentence on any accused purely based on only secondary evidence, such as, reports and photographs published in the newspapers, periodicals and magazines which are managed and controlled by the hardcore Awami League (present Government) supporters and the news presented therein are politically motivated and false as the photographs can be easily manipulated to suit the whim and fancy of the manipulator. The above section also provides that the Tribunal can admit films and tape-recordings which might be falsely made against Jamaat leaders. This is clearly against the jurisprudential principles of a fair and impartial trial and justice in all cases. The above section also goes against the well known jurisprudential principle that 'justice should not only be done but it must manifestly be seen to be done.'

Section 19(2) provides that "A Tribunal may receive in evidence any statement recorded by a Magistrate or an Investigation Officer being a statement made by any person who, at the time of the trial, is dead or whose attendance cannot be procured without an amount of delay or expense which the Tribunal considers unreasonable." (Section 19(2) of ICTA 1973).

The above subsection allows the Tribunal to admit statements made on behalf of a dead person and statement of a person who is unable to attend the court because he is very old and sick. Hence, this section might be misused against the accused as the trial is politically motivated against the Jamaat leaders. Under this subsection, the Tribunal may admit false and concocted statements presented on behalf of a dead person or a person who is unable to attend the Tribunal for age and sickness reasons.

Subsection 19(3) provides that "A Tribunal shall not require proof of facts of common knowledge but shall take judicial notice thereof." This section is very objectionable, dangerous and unacceptable in an international crimes Tribunal, because justice demands that the Tribunal must follow the well-established criminal jurisprudential principle that 'a criminal offence must be proved beyond a reasonable doubt, but this subsection is acting contrary to this well-established criminal jurisprudential principle and it is not legally acceptable for the interest of administering justice to the accused under the 1973 Act. This section talks about admitting 'common knowledge' of people without any proof. It is well-known to the people of Bangladesh that there is a false 'common knowledge' among the anti-Jamaat people in 
Bangladesh that only top Jamaat leaders committed international crimes during the liberation struggle in 1971. This 'common knowledge' was established in Bangladesh by anti-Jamaat newspapers and electronic media but it is clearly false. If the Tribunal adopts this false and fabricated 'common knowledge' without any proof, then it will be doing injustice to the accused who are in fact innocent but being summarily accused on non-corroborative grounds .

I refer again to subsection 19(1) of the ICTA 1973 as this section can be potentially misused by the AL Government to execute their notorious policy to hang the top Jamaat leaders in Bangladesh who are democratic and very much popular to the people of Bangladesh. This section of the Act states:

"A Tribunal shall not be bound by technical rules of evidence; and it shall adopt and apply to the greatest possible extent expeditious and non-technical procedure, and may admit any evidence, including reports and photographs published in newspapers, periodicals and magazines, films and tape-recordings and other materials as may be tendered before it, which it deems to have probative value."

The above section states that a Tribunal shall not be bound by "technical" rules of evidence. The use of the word "technical" is potentially prejudicial, implying that the rules of evidence are details and of little importance or value. In addition, the provision allows the Tribunal to admit evidence it deems to have "probative value", notwithstanding the "technical" rules of evidence. This probative value test appears to override the standard hearsay rule and it is questionable whether this would be consistent with the rules of other United Nations ad hoc tribunals. A probative value if not supported by the technical rules of evidence is just like a car without wheels, which is fit only for demonstration but its roadworthiness is glaringly absent. It is advisable to include some special evidentiary provisions to assist in establishing the historical facts related to the events that occurred over 40 years ago. In the interest of justice, it is recommended that (i) subsection 19(1) should be deleted from the 1973 Act. (ii) Special evidentiary provisions regarding proof of historical facts should be added to the legislation.

\section{Self-Incrimination}

Section 8 of the ICTA 1973 concerns processes of investigation under the Act. Subsection 4 and 5 of section 8 states: “(4) Any Investigation Officer making an investigation under this Act may examine orally any person who appears to be acquainted with the facts and circumstances of the case. (5) Such person shall be bound to answer all questions put to him by any Investigation Officer and shall not be excused from answering any question on the ground that the answer to such question will criminate, or may tend directly or indirectly to criminate, such person: Provided that no such answer, which a person shall be compelled to give, shall subject him to any arrest or prosecution, or be proved against him in any criminal proceeding."

Sub-section 8(7) states: "Any person who fails to appear before an Investigation Officer for the purpose of examination or refuses to answer the questions put to him by such 
Investigation Officer shall be punished with simple imprisonment which may extend to six months, or with fine which may extend to Taka two thousand or with both." (Section 8(7) of ICTA 1973).

According to the WCC of IBA, subsection 8(5) and (7) of the 1973 Act are complicated and would be difficult to use in practice. Subsection 8(5) stipulates that a person is bound to answer questions from Investigation Officers and may not be excused from answering on the grounds of self-incrimination, provided such answer does not subject that person to arrest or prosecution or be used against him in any criminal proceeding. Subsection 8(7) mentioned above provides that any person who fails to answer questions posed by an Investigation Officer shall be punished with imprisonment of up to six months or by a fine. The combination of these two provisions is confusing. Therefore, in the interest of justice and to ensure fair procedure during investigation of accused persons and witnesses, it is recommended that these two sections should be removed not only as unnecessary and redundant, but also grossly illegitimate.

Section 11(2) of the 1973 Act also addresses self-incrimination. This section states that:

"For the purpose of enabling any accused person to explain any circumstances appearing in the evidence against him, a Tribunal may, at any stage of the trial without previously warning the accused person, put such questions to him as the Tribunal considers necessary, provided that the accused person shall not render himself liable to punishment by refusing to answer such questions or by giving false answers to them; but the Tribunal may draw such inference from such refusal or answers as it thinks just."

Sub-section 11(2) of the 1973 Act allows the Tribunal to draw an inference from an accused person's refusal to answer questions or answers as it considers just. (Section 11(2) of ICTA 1973). This section must be amended as it permits the Tribunal to draw a negative conclusion from an accused person's silence. Because, such negative conclusion would nullify the right of an accused person against self-incrimination. It might be cautioned that Pakistan has never apologized for possible war crimes and this provision might force the accused to make a statement that would open him/her up to persecution or prosecution in Pakistan (WCC of IBA, 2010: 18).

Similarly, self-incriminatory provision has been incorporated in section 18 of the 1973 Act. This section raises concerns about the rights of witnesses to protection from self-incrimination. Section 18 of the Act provides:

"A witness shall not be excused from answering any question put to him on the ground that the answer to such question will criminate or may tend directly or indirectly to criminate such witness, or that it will expose or tend directly or indirectly to expose such witness to a penalty or forfeiture of any kind: Provided that no such answer which a witness shall be compelled to give shall subject him to any arrest or 
prosecution or be proved against him in any criminal proceeding, except a prosecution for giving false evidence."

The WCC of IBA in the interest of a fair procedure during an investigation or a trial of the accused or of the witnesses recommends that (i) subsection 8(5) and (7) of the 1973 Act should be removed on the basis that they are unworkable and unnecessary. (ii) Subsection 11(2) should be amended so as not to allow the Tribunal to draw a negative inference from an accused person's silence. (iii) Section 18 should be removed. (iv) Protection against self-incrimination for accused persons should be made explicit. Similar protection should be provided for witnesses as well. (NFPHR, 2010: 20).

\section{Right Of Appeal To The Appellate Division Of The Supreme Court Of Bangladesh}

The Tribunal which has been formed under the 1973 Act is equivalent to the High Court Division of the Supreme Court of Bangladesh. As a matter of fact, in Bangladesh there is no Supreme Court as found in other countries, for example, India, Malaysia and Pakistan. In Bangladesh, the Supreme Court has two divisions: i. High Court Division; and ii. Court of Appellate Division. As the Tribunal will exercise the power of the High Court Division, the accused has only the right of appeal to the Court of Appellate Division. If the Court of Appellate Division affirms the decision of the International Crimes Tribunal, then the fate of the accused would be very tragic as the case is completely politically motivated and designed for (Peter, M, 2009; Hossain, I., 2009. Another important point is that the Appellate Division of the Supreme Court of Bangladesh has no power to review the interim decisions or orders made by the Tribunal. Under the ICTA 1973 only the Tribunal has right to review its own interim decisions or orders; which is not effective when the Tribunal is subservient to the present partisan Government.

In fact, most of the judges in both Divisions of the Supreme Court of Bangladesh are pro-Government. Besides, the Attorney-General frequently interferes in the decision of both the High Court Division and the Court of Appellate Division. ${ }^{5}$ Hence, the accused has no chance of getting a fair and impartial judgment in the Court of Appeal as the case against the accused is really a political vendetta (Jalil, 2011).

According to section 21 of the 1973 Act a person convicted by a tribunal shall have the right of appeal, within sixty days of the date of order of conviction and sentence, to the Appellate Division of the Supreme Court.

Another important point was raised by the WCC of IBA and the Honorable US Senator Mr.

\footnotetext{
${ }^{5}$ Najnin Illias, News Analysis on the Speech of Barister Rafiqul Huq; Courts are Fully Under the Control of Awami League (AL) Government, The Daily Sonar Bangladesh, $1^{\text {st }}$ November, 2010. See online: http://www. Sonarbangladesh.com/article.php?ID=3930. One of the best Barristers in Bangladesh Supreme Court, Barrister Rafiqul Huq said in the second week of October 2010 in TV interview that "the judgment of the superior courts in Bangladesh changes when climate changes." In his statement Barrister Rafiqul Huq meant that since AL Government took power in January 2009, the superior courts of Bangladesh are giving decisions what AL Government wants. In other words, he meant that AL Government is totally occupying and controlling the superior courts of Bangladesh. So, fair trial and fair judgment is not possible in Bangladesh till AL Government is in power.
} 
Boozman that there should have two Chambers of the war crimes Tribunal in Bangladesh. Similarly the War Crimes Committee (WCC) of the International Bar Association (IBA) of the UK suggested that there should have been two chambers in the war crimes Tribunal in Bangladesh as practiced in other international war crimes Tribunals in the world, such as, Cambodia, Sierra Leone, etc. This was suggested to ensure fair and impartial trial of the war crimes accused in Bangladesh.

The famous British lawyer on war crimes law has commented that the Appellate Division of the High Court in Bangladesh is actually the Supreme Court of Bangladesh, therefore there is no intermediate court between the War Crimes Tribunal and the Supreme Court of Bangladesh. In this regard he has proposed that by amendment to the 1973 Act an intermediate Appeal Tribunal should be set up to hear applications or appeals against the legality of the ICTA and the Tribunal itself, the legality of the appointment of judges and prosecutors for the Tribunal, the mala fide interim decisions or orders of the Tribunal. Such proposal has been hailed by legal experts and lawyers in Bangladesh but not accepted by the AL government of Bangladesh. Hence, to get fair trial from the Tribunal an interim court or intermediate court is crucial for the accused to file applications to review the legality of interim decisions or orders of the Tribunal.

\section{Rules of Trial Procedure in the ICTA 1973}

Steven Kay QC has recently observed that The International Crimes Tribunal Act 1973 (Bangladesh) (known as ICTA 1973) does not provide the international standard procedure and the rules of evidence in the trial of top Jamaat leaders. This law is contradictory with the criminal procedure laws of Bangladesh as well as the laws of England and Wales related to criminal procedure and rules of evidence (Steven Kay QC, 2010). Section 22 of the 1973 Act provides that: "A Tribunal may regulate its own procedure". Thus, the Tribunal is given freedom to follow its own procedure it deems fit. Hence, it may not follow the proper procedure as it can even be bias and can favor the prosecution at the cost of the accused as the case is heavily politically motivated, being a high profile case.

Article 54 and 55 of the Rome statute of the International Criminal Court (ICC), respectively, set out duties and powers of the prosecution and rights of a suspect during the investigation stage. These duties and powers of the prosecution provide fair trial protections which would answer a number of potential criticisms to the ICTA 1973 procedure. Hence, it is recommended that (i) the duties and powers of the prosecution set out in Article 54 of the Rome statute should be added to the 1973 Act. (ii) The rights of a suspect during the investigation stage set out in Article 55 of the Rome statute should be added to the 1973 Act.

Section 10 of the 1973 Act governs the procedure of a trial before a tribunal. Subsection $10(1)(d)$ states that the prosecution shall make an opening statement, but there is no similar provision to allow defense counsels to do the same in which case it is rightfully recommended that a provision should be added to section 10 to allow defense counsels to make an opening statement. 


\section{Certain Important Statutes Will Be Inapplicable In The Trial Proceedings}

Section 23 of the 1973 Act clearly provides that "The provisions of the Criminal Procedure Code 1898 and Evidence Act 1972 shall not apply in proceedings under the (1973) Act.”

A fair procedure in the trial court and primary evidence to prove the alleged offences in the Tribunal are fundamental rights of every citizen of Bangladesh even if they are tried for international crimes. The fundamental rights are guaranteed under i) The constitution of Bangladesh, ii) Universal Declaration of Human Rights (UN); and iii) International Covenant on Civil and Political Rights (UN). Therefore, the 1973 Act is ultra vires and illegal and as a consequence, the Tribunal formed under the Act is also illegal as it cannot continue hearing the charges to be framed against the accused.

\section{Exclusion Of Judicial Review Power Of High Court Division}

Section 24 of the 1973 Act clearly provides "No order, judgment or sentence of a Tribunal shall be called in question in any manner whatsoever in or before any court or other authority in any legal proceedings whatsoever except in the manner provided in section 21 (of the 1973 Act)".

The above section is politically motivated and vicious. It clearly ousts one of the fundamental jurisdictions of the High Court Division that is "Judicial review power". The proper legal version of Section 24 above is that if the Tribunal makes any error of law or it acts bias or it does not follow the international standard evidence and procedure, the accused in the Tribunal has the fundamental right to move to the High Court Division under the constitution of Bangladesh with a writ petition for "Judicial review" of the decision of the Tribunal.

This shows that the 1973 Act is inconsistent with the Constitution of Bangladesh and other evidential and procedural laws and it is also inconsistent with various international conventions in which Bangladesh is a signatory, e.g., the Rome statute for International Criminal Court. As such, the 1973 Act is an illegal law and the accused cannot be tried under this law.

\section{The ICTA 1973 Can Override All Other Laws Including The Constitution Of Bangladesh.}

Selection 26 of the 1973 Act clearly provides that "The provisions of this Act shall have effect notwithstanding anything inconsistent therewith contained in any other laws for the time being in force".

This section clearly outlaws the 'Constitution of Bangladesh' which is the sacred and supreme law of the country. This makes the 1973 Act a bad and black law to try international 
crimes in the legal history of the world and this law is not accepted in the world community as it being politically motivated and it is clearly an illegal law which is not enforceable against the accused. If this 1973 Act is applied to try the accused, the accused will not get justice done.

\section{Death Penalty Provision in ICTA 1973}

Section 20(2) of the ICTA 1973 provides:

"Upon conviction of an accused person, the Tribunal shall award sentence of death or such other punishment proportionate to the gravity of the crime as appears to the Tribunal to be just and proper."

This section creates a great concern for the world community because of its provision which provides death sentence. In the modern world, death sentence is considered as inhuman and cruel. The United Nations resolutions have consistently opposed death penalty for many years. All international courts or tribunals supported by the United Nations have rejected the notion of including a death penalty as punishment for war crimes. Similarly, the War Crimes Committee (WCC) of IBA strongly contends that the ICTA 1973 (Bangladesh) should not retain death punishment for war crimes or crimes against humanity (WCC of IBA, 2010: 21). The WCC recommends that section 20(2) of the 1973 Act which allows death penalty to be used against a convicted accused person should be removed from the legislation. Unfortunately, the AL Government of Bangladesh did not heed the recommendation of the WCC of IBA in the UK.

\section{Conclusion And Suggestions}

There were six parties which opposed the separation of Bangladesh in 1971. Some neutral people and even many Freedom Fighters also committed war crimes. As such is the case, members from all those six parties, the neutral people and the Freedom Fighters who committed the 'international crimes' must be arrested and brought to the Tribunal for trial. There are people in the AL Party who also committed international crimes. However, only the top Jamaat leaders have been arrested and accused under the 1973 Act with notorious political motive. It becomes very ludicrous when one of the accused arrested for the international crimes trial from the Jamaat Party was found to be only 8 years old in 1971 . How could such a young person commit international crimes at the age of 8 . This person happened to be very lucky as he could prove his birth date through his birth certificate which happened to convince his interrogator, but what would be the likely result if his interrogator happened to be hallucinating at his post?

Such facts clearly prove that the AL Government has a mala fide political motive in the discriminatory arrest and trial of top Jamaat leaders under the 1973 Act (Islam, 2010). Therefore, the whole process of investigation and trial of the accused under the 1973 Act in the so called bias Tribunal is travesty of justice and must be stopped in the interest of a fair 
judgment in favour of the accused (Abu Rawsab, 2010; Jalil, 2011).

It is important and crucial to try the 'international criminals' under the 1973 Act but the 1973 law is defective and is not of international standard and ultra vires to the Constitution of Bangladesh and other relevant procedural laws in Bangladesh and international organizations. So, if this defective law is applied in the War Crimes Tribunals, serious socio-political and legal impact will arise. Therefore, my suggestions are:

1. To rewrite the 1973 Act so that it meets the international standard of trying 'international offences'.

Usually war crimes or international crimes are not tried by a country alone. Previous war crimes tribunals were formed by some countries in the world, for example, in Cambodia, Yugoslavia, etc., by making the United Nations (UN) as a partner. Any war crimes or international crimes tribunal must be formed by making the $\mathrm{UN}$ as a partner so that the trial process becomes impartial and fair and the accused is not persecuted for political reason. Unfortunately, in Bangladesh the AL Government is trying the accused (who have already been arrested and detained in mid 2010) for international crimes without making the UN a partner in the trial process and consequently, there is a doubt in the mind of the people of Bangladesh that the AL Government will not hold a fair and impartial trial.

As an international disgrace, in fact, the UN flatly refused to be a partner because the AL Government in Bangladesh is trying some selected political leaders for international crimes in the war crimes Tribunal after 40 years of its commission with cruel political motive. The Government took the accused for remand for more than 25 days at a time which is inhuman as many of the accused are very old and suffering from several types of complicated diseases. The police also oppressed them physically and mentally to tell a lie that they were involved in genocide and other international crimes during the liberation war between the Pakistani Government and the Freedom Fighters of Bangladesh in 1971. The present AL Government is also collecting false witnesses by offering bribes to its supporters and by threatening some people to be false witnesses against the top Jamaat leaders. This has been published in some newspapers in Bangladesh, such as, the Daily Star, The Daily Sangram, and other printed media all over the country.

Renata Lok Dessallien, the Head of the United Nations in Bangladesh said they would not be a partner with the Bangladesh Government to try the alleged war criminals but they would like to assist the Bangladesh Government by providing names of the international war crimes experts so that Bangladesh may conduct the war crimes trial fairly and impartially and does not make any mistake. She said:

"There are some countries where mistakes were made and we do not want Bangladesh to repeat those mistakes." She said, UN wants that the law under which the accused will be tried should be fair and of international standard. It must have provisions for 
appeal from the trial court to the higher courts. She also said, the UN would look into the Bangladeshi law to see whether it complied with the international war crimes legislation (AFP, 2010).

2. The criminal Procedure code, The Evidence Act and the Constitution of Bangladesh must be applied in the trial of the accused under the 1973 Act from which sections 19, 22, 23, 24 and 25 will be struck out from the 1973 Act. The fundamental procedural and evidential rights guaranteed in these Acts must be applied in the trial proceedings of the Tribunal.

3. The 1973 Act provides provisions for the Trial of 'international crimes' and the trial process under the Act must be supervised by legal experts of the 'international crimes' law who are appointed for this purpose by the UN.

4. It is recommended that there should have two Chambers in the War Crimes Tribunal in Bangladesh: i) Trial Chamber; and ii) Appeals Chamber by following the constitution of war crimes Tribunal in Sierra Leone. In the Trial Chamber, there must have at least 3 judges; 2 of them should be appointed by the United Nations and the other 1 might be appointed by the AL Government. For the Appeals Chamber, there must have at least 5 judges; 3 of whom must be appointed by the United Nations and 2 of them might be appointed by the AL Government. These judges must have the necessary expertise in the 'international crimes' law and they will sit as judges in the Tribunal under the full supervision of the UN. Such a recommended construction of the War Crimes Tribunal in Bangladesh will surely remove the doubt and suspicion of people about bias and injustice which might be caused to the accused.

5. All the judges in the Tribunal should be totally impartial persons and should not have any link or interest with the AL Government.

6. All prosecutors and investigation agency members must be impartial and fair in dealing with the investigation process. They should not be members or should not have any interest with the present Government that can make them bias persons.

7. The International Crimes Tribunal Act 1973 is an illegal law and the 'international crimes' which have been alleged and charged against the accused are available in the Penal Code of Bangladesh in which case the AL Government may try the accused under the Penal Code of Bangladesh instead of the 1973 Act and the trial under the Penal Code of Bangladesh, I am sure, will gain credibility and will be acceptable by the people of Bangladesh as well as the international community.

\section{References}

A.S.M. Rob, (2010). 'I have no evidence that Nijami, Mujahid and Saydi had committed any war crimes'. The Daily Sangram, 9 April, 2010. See web site: http://www.dailysangramcom/archive/news_details.php? news_id=28833\&publication-date-2010-04-09.

Abu Rawsab i, (2010). 'Are Jamaat-Shibir Terrorists or Victims of Terrorism?' The Daily Online Sonar Bangladesh, 13 February, 2010. See web site: 
http://www.sonarbangladesh.com/.

Abu Rawsab ii, (2010). 'Ten reasons why the war crime Tribunal is bound to be kangaroo court', The Daily Online Sonar Bangladesh, March 29, 2010. See, http://www.savebd.com/articles/ten-reasons-why-the-war-crime-tribunal-is-bound-to-be-a-ka ngaroo-court/, accessed on the web site on 30.03.2010.

AFP, (2010). 'UN to help Bangladesh crimes trial planning', The Daily Star, The Daily Sangram, 7 April, 2009. See, http://www.google.com/afp/article/AleqMSi8DOGtdott AJaQhtR_org4cmvwow, accessed to the web site on 10.4.2010.

BJI, (2009). Allegations of War Crimes against the Leaders of Bangladesh Jamaat-e-Islami: A Travesty of Truth (Dhaka, Bangladesh: Publication Department, Bangladesh Jamaat-e-Islami, 2009), at 9.

Boozman, 'John Boozman's letter to the Prime Minister of Bangladesh', April 2011.

Central Publicity Department of Jamaat. (2008). War Crimes Law and the Constitution. (Bangladesh: Central Publicity Department of Jamaat, 2008).

CPD, Jamaat, (2008). 'Text of the Bangladesh-India-Pakistan Agreement, Signed in New Delhi on 9 April, 1974', in Jamaat (ed.), War Crimes Law and the Constitution of Bangladesh (Central Publicity Department, Bangladesh Jamaat-e-Islami, Dhaka, Bangladesh, May 2008), at 24-30.

Emran Hossain, (2009). 'The Daily Star Interviews Amnesty International (AI) Asia Pacific Director Sam Zarifi', The Daily Star, 16 May, 2009. See online: http://www.thedailystar.net/newDesign/story-details.php?nid=208

Solish, Gary D., (2010). The Law of Armed Conflict: International Humanitarian Law in War. (UK, US: Cambridge University Press, 2010).

Hillary Clinton's Tele-Talk Statement with Prime Minister Sheikh Hasina in Appendix 3. Web site: http://opinion.bdnews24.com/2011/02/02/from-wikileaks-to-hillaryleak

International Crimes (Tribunals) Act 1973 (Bangladesh).

Islam, Syed Serajul and Islam, Md Saidul, (2010). 'War Crimes Tribunal in Bangladesh: A Contested Move', The Online Sonar Bangladesh, 1st April, 2010. See online: http://www.sonarbangladesh. com/articles/SerajulIslamSaidulIslam, accessed to the internet on 23.12.2010;

Jalil, Md. Abdul, (2011). 'Human Rights Violation and Political Persecution in Bangladesh: 
The Current Scenery', 3(1) Asian Culture and Society 46-53 (2011).

Jalil, Md. Abdul, (2010). 'War Crimes Trial in Bangladesh: A Real Political Vendetta', 3(2) Journal of Politics and Law 110-120 (September 2010). See web site: www.ccsenet.org/jpl

Jalil, Md. Abdul and Rahman, Md. Khalilur, (2011). 'Arrest and Police Remand Issue of Top Jamaat Leaders in Bangladesh: Under the Guise of Hurting the Religious Sentiments of Muslims', 7(1) Asian Social Science 77-87 (January 2011).

Juan J. Quintana. (2010). Procedural Developments at the International Court of Justice, 9(2) The Law and Practice of International Courts and Tribunal 327-400 (2010).

Khan, M.N.I., The legal infirmities of the International Crimes (Tribunal) Act, 1973, The Weekly Blitz, August 20, 2010. See web site: http://www.weeklyblitz.net/948/the-legal-infirmities-of-the-international-crimes, accessed to the web site on 05.12.2010.

Marijke Peter, (2009). 'Fair War Crimes Trial in Bangladesh: Observation of Human Rights Watch Asia Director Adam Brady', The Daily Star, 9 July 2009;

Najnin Illias, 2009. 'News Analysis on the Speech of Barister Rafiqul Huq; Courts are Fully under the Control of Awami League (AL) Government', The Daily Sonar Bangladesh, $1^{\text {st }}$ November, 2010. See online: http://www. Sonarbangladesh.com/article.php?ID=3930.

NFPHR, (2010). Conference on the Legality of the International Crimes (Tribunals) Act 1973 (Dhaka, Bangladesh: The National Forum for Protection of Human Rights (NFPHR), 2010), at 20 .

Stephen Rapp, (2011). 'The War Crimes Trial Must be in Accordance with ICC Standard', The Daily Amar Desh, 14 January, 2011. See web site: http://www.amardeshonline.com/pages/details/2011/10/14/63083, accessed to the internet on 15.01.02011

Steven Kay QC, (2010). 'Bangladesh International Crimes (Tribunals) Act 1973 - Update', International Crimes Law Bureau, 9 July, 2010. See online: http://www.internationallawbureau.com/blog/?p=1554, accessed to the Internet on 04.12.2010. War Crimes Committee (WCC) of IBA, UK, (2010). Inconsistency of Bangladesh's International Crimes (Tribunals) Act 1973 with International Standards. Dhaka, Bangladesh: Society Watch, 2010.

Wikipedia, (2010). 'History of Pakistan'. web site: http://en.wikipedia.org/wiki/ History_of_Pakistan, accessed to the internet on 05.12.2010. 
Wikipedia, (2010). 'History of Bangladesh' (1947-1971). See web site: http://en.wikipedia.org/ wiki/History_of_Bangladesh_(1947-1971), accessed to the internet on 05.12.2010.

Yoshi Kodama, (2010). 'For judicial justice and reconciliation in Cambodia: reflections upon the establishment of the Khmer Rough Trials and the Trials' Procedural Rules 2007', The Law and Practice of International Courts and Tribunals, Vol. 2, 2010, pp. 37-113. 